\title{
THE USEFULNESS OF FLASH EUROBAROMETER TO STUDY CHANGES IN TOURISTS' PREFERENCES
}

\author{
MARIAN GÚČIK, ${ }^{1}$ ANDRZEJ RAPACZ, ${ }^{2}$ DARIA ElŻBIETA JAREMEN ${ }^{3}$ \\ ${ }^{1}$ Univerzita Mateja Bela, Banska Bystrica, Slovakia \\ e-mail: marian.gucik@umb.sk \\ ${ }^{2}$ Wrocław University of Economics \\ e-mail: andrzej.rapacz@ue.wroc.pl \\ ${ }^{3}$ Wrocław University of Economics \\ e-mail: daria.jaremen@ue.wroc.pl
}

\section{JEL CODES}

KEYWORDS

ABSTRACT
C83, D10, Z33

Flash Eurobarometer, tourists' preferences, source of information

The effective functioning of tourist enterprises requires, among others, good knowledge of their customers' purchasing preferences. Secondary sources, e.g. the available research reports, may turn out helpful in this respect. The purpose of this article is to assess the usefulness of Flash Eurobarometer research results to analyse changes in the European tourists' preferences, with particular emphasis on Poles and Slovaks. As it turns out, the aforementioned source of information is not free from certain deficiencies. It mainly refers to the systematic changes made in terms of the substantive scope of the measuring instrument, i.e. the questionnaire. They consist in introducing new questions to the questionnaire, changes in previous questions and variants of answers to the questions. Such changeability reduces significantly the possibility of comparing information in the studied period and their usefulness for entrepreneurs and representatives of the world of science.

\section{Introduction}

The changing behaviour patterns of tourists have impact on market behaviours presented by entrepreneurs. For the effective functioning of tourist enterprises, the knowledge of customers' purchasing preferences becomes increasingly important. On the one hand, it provides entrepreneurs with the suitable selection and satisfying service for target groups of clients and, on the other, it allows to improve the offer characterised by the features most desirable by tourists. Therefore, 
the owners and managers of tourist enterprises should systematically get acquainted with the available research reports, which extend their knowledge regarding the changing trends observed in tourist demand. In these conditions it is important that secondary research, the results of which may be used by the operators either against payment or free of charge, meet the conditions of high usefulness.

As long as for the last four decades, the studies on the European citizens' preferences and attitudes towards tourism, called Flash Eurobarometer, have been conducted by the European Commission Directorate-General. Since 1986, twelve of their cycles have been carried out, and since 2009 they have been systematically performed at annual intervals. Thus, it may seem that the attribute of regular measurement covering the same phenomenon should support the application of its results for comparative research and the identification of changes in customer preferences on the tourism market.

The purpose of this article is to assess the usefulness of Flash Eurobarometer research results in order to analyse certain problems in the area of tourism, and in this case the changes in the European tourists' preferences, with particular emphasis on Poles and Slovaks. The implementation of the research objective required, on the one hand, solving the selected research problem (the evolution of tourists' preferences) and, on the other, establishing a specific criterion pattern, i.e. the set of criteria for the analysis of the usefulness of secondary sources, for the purposes of the specific research. In the first case, tourists' preferences were defined and the variables subject to comparison were selected. In the second, based on the paradigm generally applicable in marketing research, a criterion pattern for the secondary measurement evaluation was developed. It was also assumed that the pattern will cover factors determining its credibility, i.e. accessibility, accuracy, timeliness, relevance and comparability. The basic research method was the analysis of the content of Flash Eurobarometer reports from the years 2009-2016.

\section{Flash Euroharometer - the methodological issue}

The originator of Eurobarometers was M. Jaques-Rene Rabier - Head of the Information Service of the Communities and he directed the Eurobarometer surveys from their inception until 1986. Flash Eurobarometer is a part of the much larger system of four types of Eurobarometer surveys, i.e. (Spotlight..., 2014, p. 5):

1. Standard Eurobarometer surveys - a reference on European public opinion, with faceto-face surveys at respondents' homes done twice a year (Spring-Autumn) by European Commission Directorate-General since 1974.

2. Special (SP) Eurobarometer surveys - a primary tool for capturing the opinion of the general public on specific issue, with face-to-face surveys at respondents' homes.

3. Flash (FL) Eurobarometer surveys - telephone surveys for the polling of specific target groups or the general public with short questionnaires.

4. Eurobarometer studies - focus group or in-depth interviews, allowing for detailed understanding of public opinion on a specific subject, the qualitative studies investigate 
in-depth the motivations, feelings and reactions of selected social groups towards a given subject or concept, by listening to and analysing their way of expressing themselves in discussion groups or with non-directive interviews.

The study was established in 1974, though the first such survey took place in 1962. The research was repeated at the beginning of 1970 and in the summer of 1971 . There was no continuity between surveys, but they have shown to the European Parliament the need of a regular mechanism for monitoring the European opinion (Entretien..., 2003). In the foreword to Eurobarometer Almanac 2013 it is written that Eurobarometer "is widely regarded as a reference point for European public opinion and it helps to see how public opinion is changing. The study allows understanding how the European project and its developments impact the life of Europeans and provides information to feed into policy-making for the European Union and is institutions" (Spotlight.., 2014, p. 5).

The rationale for conducting systematic research evolved in the course of over forty years long history of Eurobarometer. At the beginning, the aim was to help Europeans see and understand each other, and to investigate the existence of the 'European public opinion'. Then it was aimed at analysing trends of public attitude towards EU in general and its core policies. Today, the European Union institutions are interested in trends, national specificities, and socio-demographic variables determining attitudes of Europeans towards varied economic and social phenomena (Table 1). The field of interest is also the regional diversity of the Europeans' opinions on these issues, and therefore the research serves a comparative purpose.

Table 1. Number of Eurobarometer surveys by topics in the period 1972-2018 (data provided for topics covered by ten and more surveys)

\begin{tabular}{lll}
\hline \multicolumn{1}{c}{$\begin{array}{c}\text { Surveys' subject } \\
\text { (the number of surveys) }\end{array}$} & \multicolumn{1}{c}{$\begin{array}{c}\text { Surveys' subject } \\
\text { (the number of surveys) }\end{array}$} & $\begin{array}{c}\text { Surveys' subject } \\
\text { (the number of surveys) }\end{array}$ \\
\hline Agriculture (16) & Euro - general (46) & Innovation (12) \\
Businesses (26) & Euro in European countries (44) & Internet (17) \\
Consumer affairs (15) & Europe 2020 (10)European citizenship (11) & Justice (15) \\
Consumer rights in European countries (29) & European citizenship and fundamental rights (22) & Regions and regional policy (12) \\
Cross-border trade and consumer protection (14) & European Constitution (12) & Science, technology, research and innovation (15) \\
Development aid and relations with developing & Future of Europe (12) & Standard Eurobarometer (88) \\
countries (21) & Gender equality (11) & Tobacco (11) \\
Employment and social policy (15) & General surveys (24) & Tourism (12) \\
Energy (14) & Health and food safety (23) & Transport (11) \\
Environment (14) & Information society (13) & United Kingdom (10) \\
& & Youth (12) \\
\hline
\end{tabular}

Source: authors' compilation based on Eurobarometer... (2018).

Most of the Eurobarometer surveys referring to tourism are carried out in the formula of short telephone surveys (Flash Eurobarometer) to measure attitudes and preferences of Europeans towards tourism (Table 2). The first three studies conducted in 1986, 1997 and 1998, belonged to the Special Eurobarometer surveys (in-depth thematic studies carried out for various services of the European Commission or other EU Institutions and integrated in the Standard Eurobarometer's polling waves). 
Table 2. Flash Eurobarometer overview by tourism topics in the period 1972-2018

\begin{tabular}{|c|c|c|c|c|}
\hline Title & $\begin{array}{c}\mathrm{EU} \\
\text { document }\end{array}$ & Year & $\begin{array}{c}\text { Number } \\
\text { of respondents }\end{array}$ & $\begin{array}{c}\text { Number } \\
\text { of variables }\end{array}$ \\
\hline $\begin{array}{l}\text { Preferences of Europeans towards tourism, } 2016 \\
\quad(\text { EU28 + TR + MK + IS + ME + MD) }\end{array}$ & FL432 & 2016 & 30,105 & 625 \\
\hline $\begin{array}{l}\text { Preferences of Europeans towards tourism, } 2015 \\
\qquad(\mathrm{EU} 28+\mathrm{TR}+\mathrm{MK}+\mathrm{IS}+\mathrm{RS}+\mathrm{ME}+\mathrm{MD})\end{array}$ & FL414 & 2015 & 30,111 & 629 \\
\hline $\begin{array}{l}\text { Attitudes of Europeans towards tourism, } 2014 \\
\qquad(\mathrm{EU} 28+\mathrm{TR}+\mathrm{MK}+\mathrm{RS}+\mathrm{ME}+\mathrm{NO}+\mathrm{IS}+\mathrm{IL})\end{array}$ & FL392 & 2014 & 31,112 & 623 \\
\hline $\begin{array}{l}\text { Attitudes of Europeans towards tourism, } 2013 \\
\qquad(\mathrm{EU} 27+\mathrm{TR}+\mathrm{HR}+\mathrm{MK}+\mathrm{RS}+\mathrm{NO}+\mathrm{IS}+\mathrm{IL})\end{array}$ & FL370 & 2013 & 30,628 & 553 \\
\hline $\begin{array}{l}\text { Survey on the attitudes of Europeans towards tourism, } 2012 \\
\quad(\text { EU27 + TR + HR + MK + RS + NO + IS + IL) }\end{array}$ & FL334 & 2012 & 30,594 & 340 \\
\hline $\begin{array}{l}\text { Survey on the attitudes of Europeans towards tourism, } 2011 \\
\text { (EU27 + TR + MK + NO + IS) }\end{array}$ & FL328 & 2011 & 30,158 & 54 \\
\hline Attitudes of Europeans towards tourism, $2010(\mathrm{EU} 27+\mathrm{TR}+\mathrm{MK}+\mathrm{NO}+\mathrm{IS})$ & FL291 & 2010 & 30,138 & 56 \\
\hline Attitudes of Europeans towards tourism, autumn 2009 & FL281 & 2009 & 23,606 & 57 \\
\hline Survey on the attitudes of Europeans towards tourism, spring 2009 & FL258 & 2009 & 27,127 & 68 \\
\hline Europeans and their views on child sex tourism & SP118 & 1998 & 16,165 & 27 \\
\hline Europeans on holiday & SP117 & 1997 & 16,186 & 15 \\
\hline Europeans and their holidays & SP028 & 1986 & 11,840 & 18 \\
\hline
\end{tabular}

Explanation: EU27 (European Union - 27 Member States), EU28 (European Union - 28 Member States), HR (Croatia), IL (Israel), IS (Iceland), ME (Montenegro), MD (Moldova), MK (Former Yugoslav Republic of Macedonia), NO (Norway) TR (Turkey), RS (Republic of Serbia).

Source: own compilation based on Europeans and their Holidays, SP028 (1987), pp. III, 1, http://ec.europa.eu/commfrontoffice/ publicopinion/index.cfm/Survey/getSurveyDetail/yearFrom/1986/yearTo/2018/search/HOLIDAY/surveyKy/86; Europeans on holiday, SP117 (1997), pp. III, 15, http://ec.europa.eu/commfrontoffice/publicopinion/index.cfm/Survey/getSurveyDetail/yearFrom/1974/yearTo/1998/search/HOLIDAY/surveyKy/172; Europeans and their views on child sex tourism, SP118 (1998), pp. III, 28, http://ec.europa.eu/commfrontoffice/publicopinion/index.cfm/Survey/getSurveyDetail/yearFrom/1974/year To/2000/search/ sex\%20tourism/surveyKy/173; https://www.gesis.org/eurobarometer-data-service/survey-series/ flash-eb/study-overview.

The Flash Eurobarometer surveys on the attitudes and preferences of Europeans towards tourism are conducted for the European Commission, Internal Market, Industry, Entrepreneurship and SMEs, Directorate-General for Communication, "Strategy, Corporate Communication Actions and Eurobarometer" Unit. Each survey consists of approximately 500-1,500 interviews per country. The number of interviews depends on the number of citizens in the country. Every year approximately 30 thousands randomly selected Europeans aged 15 and over from 27-34 European countries and Israel (2011-2013) take part in the study. FL surveys are carried every year in January-February. The majority of surveys are web-based computer-assisted telephone interviews, some of them are face-to-face interviews (e.g. in Bulgaria, the Czech Republic, Estonia, Latvia, Lithuania, Hungary, Poland, Romania and Slovakia). Flash Eurobarometer surveys systematically include mobile phones (in samples in Austria, Finland, Italy, Portugal and Spain). Reports are published online once a year and are accessible for all. The surveys are designed and conducted very professionally by leading global market, public opinion and media research network TNS Political \& Social. The aim of each survey, since the initial one in 2009, is exploring the range of aspects regarding holidays in the analysed period/year. Some of the studied topics are the same (Table 3), which makes long-term analyses possible as well as comparing the current survey results with the previous ones. 
Tahle 3. Topics of surveys addressing attitudes/preferences of Europeans towards tourism in the period 2009-2016

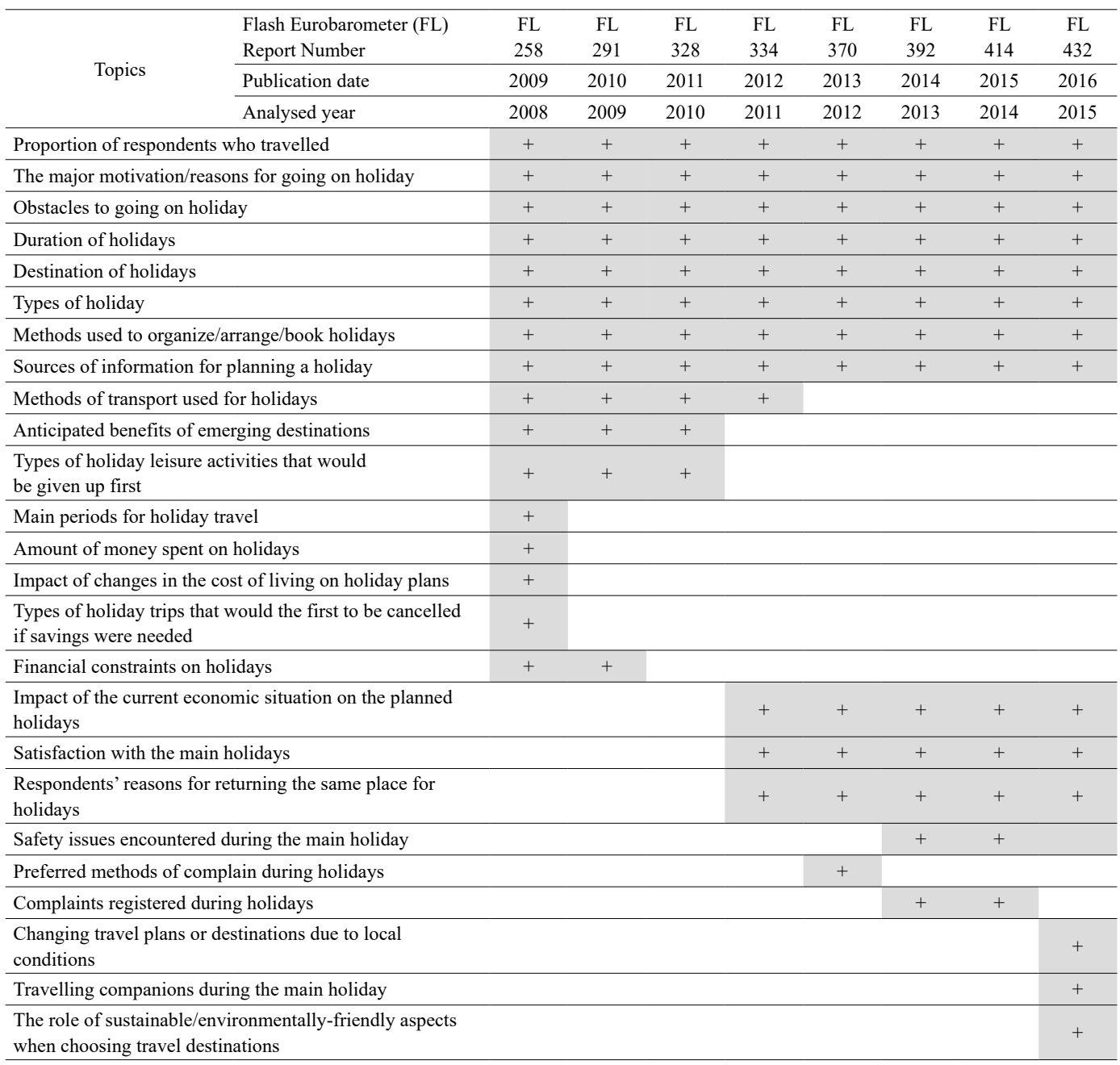

Source: authors' compilation based on FL Reports: Survey on the attitudes of Europeans towards tourism, FL258, 2009; Attitudes of Europeans towards tourism, FL291 (2010); Survey on the attitudes of Europeans towards tourism, FL328 (2011); Survey on the attitudes of Europeans towards tourism, FL334 (2012); Attitudes of Europeans towards tourism, FL370 (2013); Attitudes of Europeans towards tourism, FL392 (2014); Preferences of Europeans towards tourism, FL414 (2015); Preferences of Europeans towards tourism, FL432 (2016).

The analysis of the structure, content and form of measurement instruments (questionnaires) used in the study in the period 2009-2016 indicates their high variability over time. Surveys are modified in every research cycle and it does not only refer to adding or eliminating problems of interest to researchers, but also to changing the phrasing and scaling of questions, even in the case of the same phenomenon analysed since the first Flash Eurobarometer was initiated in 2009 (Table 4). 
Table 4. Examples of changes in FL measuring instrument (survey) in selected years

\begin{tabular}{|c|c|c|c|}
\hline \multirow{2}{*}{ Topics } & \multicolumn{3}{|c|}{ Question } \\
\hline & FL258/2009 & FL334/2012 & FL432/2016 \\
\hline $\begin{array}{l}\text { The major } \\
\text { motivation/ } \\
\text { reasons for } \\
\text { going on } \\
\text { holidays. }\end{array}$ & $\begin{array}{l}\text { Q6. What was the major motivation } \\
\text { for your main holiday trip in } 2008 \text { ? } \\
\text { (choose one) } \\
\text { - Sun/beach } \\
\text { - Wellness/health treatment } \\
\text { - Rest/recreation } \\
\text { - City trips } \\
\text { - Sport-related } \\
\text { - Nature } \\
\text { - Culture/ religion } \\
\text { - Visiting friends/relatives } \\
\text { - Don't know/no answer }\end{array}$ & $\begin{array}{l}\text { Q6. What were your main reasons } \\
\text { for going on holiday in } 2011 \text { ? (max. } \\
3 \text { answers) } \\
\text { - Sun/beach } \\
\text { - Wellness/health treatment } \\
\text { - Rest/recreation } \\
\text { - City trips } \\
\text { - Sport-related } \\
\text { - Nature } \\
\text { - Culture/ religion } \\
\text { - Visiting friends/relatives } \\
\text { - Other (do not read out) } \\
\text { - Don't know/no answer }\end{array}$ & $\begin{array}{l}\text { Q5A. What were your main reasons for going } \\
\text { on holiday in } 2015 \text { ? Firstly? (one answer } \\
\text { only) } \\
\text { - Sun/beach } \\
\text { - Wellness/Spa/health treatment } \\
\text { - City trips } \\
\text { - Sport-related activities (e.g. scuba-diving, } \\
\text { cycling etc.) } \\
\text { - Nature (mountain, lake, landscape, etc.) } \\
\text { - Culture (e.g. religious, gastronomy, arts) } \\
\text { - Visiting family/friends/relatives } \\
\text { - Specific events (sporting events/festivals/ } \\
\text { clubbing) } \\
\text { - Other (do not read out) } \\
\text { - Don't know/no answer } \\
\text { Q5B. And then? (max. } 3 \text { answers) } \\
\text { - the same options as above ... }\end{array}$ \\
\hline $\begin{array}{l}\text { Sources of in- } \\
\text { formation } \\
\text { for planning } \\
\text { holidays. }\end{array}$ & $\begin{array}{l}\text { Q19a. From the following informa- } \\
\text { tion sources, which one do you } \\
\text { consider to be the most important } \\
\text { when you make a decision about } \\
\text { your travel /holiday plans? } \\
\text { - Personal experience } \\
\text { - Recommendations of friends } \\
\text { and colleagues } \\
\text { - Guidebooks and magazines } \\
\text { (commercial) } \\
\text { - Catalogues, brochures } \\
\text { (non-commercial) } \\
\text { - The Internet } \\
\text { - Travel / tourist agencies } \\
\text { - Media (newspaper, radio, TV) } \\
\text { - Don't know/no answer } \\
\text { Q19b. And what is the second most } \\
\text { important? } \\
\text { - the same options as above... }\end{array}$ & $\begin{array}{l}\text { Q12. From the following informa- } \\
\text { tion sources, which one do you } \\
\text { consider to be the most important } \\
\text { when you make a decision about } \\
\text { your travel plans? } \\
\text { - Personal experience } \\
\text { - Recommendations of friends, } \\
\text { colleagues or relatives } \\
\text { - Paid for guidebooks and } \\
\text { magazines } \\
\text { - Free Catalogues, brochures } \\
\text { - Social media sites } \\
\text { - Travel / tourist agencies } \\
\text { - Newspaper, radio, TV } \\
\text { - Other (do not read out) } \\
\text { - Don't know/no answer }\end{array}$ & $\begin{array}{l}\text { Q9. Which of the following information } \\
\text { sources do you think are the most important } \\
\text { when you make a decision about your travel } \\
\text { plans? } \\
\text { - Personal experience } \\
\text { - Recommendations of friends, colleagues or } \\
\text { relatives } \\
\text { - Paid for guidebooks and magazines } \\
\text { - Websites collecting and presenting com- } \\
\text { ments, reviews and ratings from travelers } \\
\text { - Websites run by service provider or } \\
\text { destination } \\
\text { - Online social media pages (for accommoda- } \\
\text { tion, restaurants, transport companies, etc.) } \\
\text { - Counters of travel agencies and tourism } \\
\text { office } \\
\text { - Newspaper, radio, TV } \\
\text { - Other (do not read out) } \\
\text { - Don't know/no answer Destination } \\
\text { of holidays }\end{array}$ \\
\hline $\begin{array}{l}\text { Destination } \\
\text { of holidays. }\end{array}$ & $\begin{array}{l}\text { Q7. Where did you travel for your } \\
\text { main holiday in } 2008 ?\end{array}$ & $\begin{array}{l}\text { Q5. To which country(ies) did you } \\
\text { go for a minimum } 4 \text { nights in } 2011 \text { ? }\end{array}$ & $\begin{array}{l}\text { Q4A. In which country did you spend your } \\
\text { main holiday in } 2015 \text { ? } \\
\text { Q4T. In which country did you spend your } \\
\text { holiday in } 2015 \text { ? }\end{array}$ \\
\hline
\end{tabular}

Source: authors' compilation based on FL Reports: Survey on the attitudes of Europeans towards tourism, FL258 (2009); Survey on the attitudes of Europeans towards tourism, FL334 (2012); Preferences of Europeans towards tourism, FL432 (2016).

\section{Tourist preferences - the essence}

The preference category derives from the Latin term "praeferr" ("I prefer something to something else") and originates from the theory of utility used in economics in order to explain consumers' behaviour and, in particular, their market choices. The concept of preferences is used to quantify usability, which cannot be measured directly (Pełka, Rybicka, 2012, pp. 302-315). Preferences 
can only be talked about when an individual faces the choice of one of many options - action, commodity, friend, etc. (Kowalik, 1994, pp. 97-111). Preferences express the subjective attitude of a consumer to goods and allow for determining which of them are considered the best in the context of satisfying needs (Bazarnik, Grabiński, Kąciak, Mynarski, Sagan, 1992, p. 80). It is assumed that they do not depend on the prices of consumer goods or on the budget at consumer's disposal, but on the satisfaction resulting from their use (consumption) only. In the classical theory of rational choice, preferences represent the subjective states resulting in actions, i.e. making decisions about the size and structure of present and/or future consumption and, in consequence, about making the purchase. Preferences are used to examine individual purchasing decisions which, in turn, facilitate the analysis of an effective market demand. Tourist preferences refer to consumer priorities in the tourist market. They are manifested in the preferred travelling directions, destinations, the way of organizing a journey, the length of stay, the dates of making tourist trips, as well as in the choices regarding the type of accommodation and recreation services in the destination. Preferences do not represent a permanent category, they can undergo transformations, can be modelled (Szymańska, 2012, pp. 67-86), and thus influenced by the suppliers of products and services, for example, through marketing activities, such as promotion in particular.

\section{Tourist preferencees of Poles and Slovals in the years 2008-2015 in the light of Flash Euroharometer}

The purpose of the research, as it has been mentioned in the introduction, was to compare tourism preferences of Europeans, in the period 2008-2015, highlighting those of Poles and Slovaks. The data presented in Flash Eurobarometer reports, from the period 2009-2016, constituted the basis of the conducted analysis. Initially it was assumed that the preferences will be described as broadly as it is allowed by the substantive scope of the reports. The previous section of the article identifies eight problems for which data were collected cyclically in each studied year, since the beginning of Flash Eurobarometer functioning. Therefore, the study of preference variability over the time, selected for the discussed research could refer to the aforementioned eight issues. Nevertheless, an in-depth analysis of the content of questions and the variables of measurement scales used limited additionally the subject of research to three factors, which was still burdened by certain difficulties. The following characteristics were compared: (1) major motivation/reasons for going on holiday; (2) obstacles to going on holiday and (3) main reason for not going on holiday.

Since the first Flash Eurobarometer survey was carried out in 2009, until the most recent one in 2016, the total of 263,579 people were surveyed, at an annual average of 29,287 citizens, mainly from the European countries. In the surveyed population the number of Poles was slightly over 1,500 per year, whereas Slovaks - 1,000 people (Table 5). 
Table 5. Number of respondents

\begin{tabular}{|c|c|c|c|c|c|c|c|c|c|}
\hline \multirow{3}{*}{ Specification } & \multirow{2}{*}{\multicolumn{3}{|c|}{ Polish }} & \multirow{2}{*}{\multicolumn{3}{|c|}{ Slovaks }} & \multicolumn{3}{|c|}{ EU Citizens } \\
\hline & & & & & & & EU27 & EU27 & EU28 \\
\hline & 2008 & 2011 & 2015 & 2008 & 2011 & 2015 & 2008 & 2011 & 2015 \\
\hline Number of respondents & 1,515 & 1,501 & 1,501 & 1,014 & 1,001 & 1,000 & 27,127 & 26,523 & 27,070 \\
\hline
\end{tabular}

Source: authors' compilation based on FL Reports: Survey on the attitudes of Europeans towards tourism, FL258 (2009); Survey on the attitudes of Europeans towards tourism, FL334 (2012); Preferences of Europeans towards tourism, FL432 (2016).

The analysis of answers provided to the questions contained in the Flash Eurobarometer questionnaire allows for noticing an ongoing increase in tourism participation, in terms of both Polish citizens (from $59.7 \%$ in 2008 up to $72.5 \%$ in 2015) and Slovakian ones (from $58.2 \%$ up to $73.9 \%$ ) (Table 6). The increase rate in the number of Poles and Slovaks traveling for tourism purposes was definitely higher than the average values in this respect for all the European Union countries. In 2015 the level of the analysed characteristics, regarding the residents of Poland and Slovakia, was very similar to the one for the EU residents, and amounted to about $73 \%$ (Table 6).

Table 6. Proportion of respondents who travelled in 2008, 2011 and 2015 (\%)

\begin{tabular}{|c|c|c|c|c|c|c|c|c|c|}
\hline \multirow{3}{*}{ Specification } & \multirow{2}{*}{\multicolumn{3}{|c|}{ Polish }} & \multirow{2}{*}{\multicolumn{3}{|c|}{ Slovaks }} & \multicolumn{3}{|c|}{ EU Citizens } \\
\hline & & & & & & & EU27 & EU27 & EU28 \\
\hline & 2008 & 2011 & 2015 & 2008 & 2011 & 2015 & 2008 & 2011 & 2015 \\
\hline Have travelled & 59.7 & 69 & 72.5 & 58.2 & 72 & 73.9 & 70.9 & 72 & 73.3 \\
\hline Have not travelled at all & 38.2 & 27 & 26.5 & 37.2 & 24 & 24.7 & 27.7 & 26 & 26.0 \\
\hline Don't know/no answer & 2.1 & 4 & 1.0 & 4.6 & 4 & 1.4 & 1.4 & 2 & 0.7 \\
\hline
\end{tabular}

Source: authors' compilation based on FL Reports: Survey on the attitudes of Europeans towards tourism, FL258 (2009); Survey on the attitudes of Europeans towards tourism, FL334 (2012); Preferences of Europeans towards tourism, FL432 (2016).

Apart from some differences in the nominal response scale, used in the question about the reasons of traveling for tourism purposes, it should be noted that in the case of Poles, four factors are relevant as tourist motivations in the following sequence: nature (49\%), city trips (42\%), visiting family/friends/relatives (41\%) and sun/beach (40\%). The important ones for Slovaks are: sun/beach (38\%), nature (29\%) and visiting family/friends/relatives (29\%). Among the motives for traveling, year by year, the most important role is played - for both groups of respondents - by: city trips, nature, VR and sun/beach. The importance of sport-related activities and culture is also growing (Table 7).

In spite of repeated, relatively significant discrepancies in the part of the research instrument, measuring major barriers to the participation of the EU residents in tourism, it can be assumed that in the case of Europeans, and also Poles and Slovaks, the long-term invariable and basic factor limiting the possibilities of making tourist trips are financial reasons regardless of the respondent's nationality (Table 8). The second unfavourable factor for undertaking tourist trips is connected with personal and health reasons, whereas the third important factor is the lack of time for various reasons (work, family). 
Table 7. Main reasons for going on holidays in 2008, 2011 and 2015 (\%)

\begin{tabular}{|c|c|c|c|c|c|c|c|c|c|}
\hline \multirow{3}{*}{ Specification } & \multirow{2}{*}{\multicolumn{3}{|c|}{ Polish }} & \multirow{2}{*}{\multicolumn{3}{|c|}{ Slovaks }} & \multicolumn{3}{|c|}{ EU Citizens } \\
\hline & & & & & & & EU27 & EU27 & EU28 \\
\hline & 2008 & 2011 & $2015^{\mathrm{a}}$ & 2008 & 2011 & $2015^{\mathrm{a}}$ & 2008 & 2011 & $2015^{\mathrm{a}}$ \\
\hline Rest/recreation & 49 & $52^{\mathrm{b}}$ & - & 39 & $49^{\mathrm{b}}$ & - & 37 & $48^{\mathrm{b}}$ & - \\
\hline Sun/beach & 16 & 20 & 40 & 28 & 25 & 38 & 20 & 28 & 39 \\
\hline Visiting family/friends/relatives & 12 & 28 & 41 & 12 & 26 & 29 & 16 & 28 & 38 \\
\hline Nature (mountain, lake, landscape, etc.) & 5 & 22 & 49 & 8 & 19 & 35 & 6 & 18 & 31 \\
\hline City trips & 8 & 21 & 42 & 3 & 11 & 20 & 7 & 16 & 27 \\
\hline Sport-related activities (e.g. scuba-diving, cycling, etc.) & 3 & 8 & 19 & 5 & 8 & 16 & 3 & 10 & 12 \\
\hline Culture (e.g. religious, gastronomy, arts) & 2 & 8 & 16 & 1 & 10 & 24 & 7 & 14 & 26 \\
\hline Spending time with your family & - & 37 & - & - & 28 & - & - & 32 & - \\
\hline Wellness/Spa/health treatments & 5 & - & 8 & 4 & - & 25 & 3 & - & 13 \\
\hline Specific events (sporting events/ festivals/clubbing) & - & - & 11 & - & - & 8 & - & - & 9 \\
\hline
\end{tabular}

Explanation: ${ }^{\mathrm{a}}$ Firstly? And then?; ${ }^{\mathrm{b}}$ including Wellness/health treatments.

Source: authors' compilation based on FL Reports: Survey on the attitudes of Europeans towards tourism, FL258, 2009; Survey on the attitudes of Europeans towards tourism, FL334, 2012; Preferences of Europeans towards tourism, FL432, 2016.

Table 8. Main reasons for not going on holidays in 2008, 2011 and 2015 (\%)

\begin{tabular}{|c|c|c|c|c|c|c|c|c|c|}
\hline \multirow{3}{*}{ Specification } & \multirow{2}{*}{\multicolumn{3}{|c|}{ Polish }} & \multirow{2}{*}{\multicolumn{3}{|c|}{ Slovaks }} & \multicolumn{3}{|c|}{ EU Citizens } \\
\hline & & & & & & & \multirow{2}{*}{$\frac{\text { EU27 }}{2008}$} & \multirow{2}{*}{$\begin{array}{r}\text { EU27 } \\
2011 \\
\end{array}$} & \multirow{2}{*}{$\begin{array}{l}\text { EU28 } \\
2015^{\mathrm{a}}\end{array}$} \\
\hline & 2008 & 2011 & $2015^{\mathrm{a}}$ & 2008 & 2011 & $2015^{\mathrm{a}}$ & & & \\
\hline Financial reasons & 52 & 51 & 57 & 37 & 51 & 54 & 41 & 45 & 51 \\
\hline Personal/private reasons & 16 & 17 & - & 19 & 24 & - & 21 & 23 & - \\
\hline Health reasons & - & - & 26 & - & - & 31 & - & - & 23 \\
\hline Preferred to stay at home or with family/friends & 9 & 9 & $22^{\mathrm{b}}$ & 12 & 8 & $20^{\mathrm{b}}$ & 9 & 11 & $22^{\mathrm{b}}$ \\
\hline You did not want to go on holiday/no motivation to take a holiday & 1 & 2 & - & 5 & 1 & - & 4 & 4 & - \\
\hline Lack of free time due to work or study commitments & \multirow{2}{*}{$11^{\mathrm{c}}$} & \multirow{2}{*}{$12^{\mathrm{c}}$} & 30 & \multirow{2}{*}{$12^{\mathrm{c}}$} & \multirow{2}{*}{$8^{\mathrm{c}}$} & 19 & \multirow{2}{*}{$10^{\mathrm{c}}$} & \multirow{2}{*}{$9^{c}$} & 20 \\
\hline Lack of free time due to family commitments & & & 28 & & & 17 & & & 19 \\
\hline Prefer to make short-stay trips only & 0.4 & - & - & 4 & - & - & 2 & - & - \\
\hline Concerns about safety & 0.5 & 1 & - & 0.2 & 1 & - & 1 & 0 & - \\
\hline Problems of accessibility of transport or accommodation & - & 0 & - & - & 0 & - & - & 1 & - \\
\hline Lack of facilities for person with disabilities & - & - & 4 & - & - & 3 & - & - & 2 \\
\hline Administrative problems (getting a visa, etc.) & - & - & 0 & - & - & 1 & - & - & 1 \\
\hline Others & 7 & 8 & 6 & 9 & 4 & 20 & 8 & 6 & 14 \\
\hline
\end{tabular}

Explanation: ${ }^{\mathrm{a}}$ Firstly? And then?; ${ }^{\mathrm{b}}$ including no motivation to take a holiday; ${ }^{\mathrm{c}}$ lack of time.

Source: authors' compilation based on FL Reports: Survey on the attitudes of Europeans towards tourism, FL258 (2009); Survey on the attitudes of Europeans towards tourism, FL334 (2012); Preferences of Europeans towards tourism, FL432 (2016).

The analysis of the third variable, in the case of which at least partial and cautious comparisons can be made in the dynamic system, provides for the following conclusions (Table 9):

- firstly, significant changes occur in the sources of information used by tourists in the process of their trip planning, 
- recommendations of friends, colleagues or relatives still remain basic information source for trip planners, even though their significance declines, especially for the respondents from Slovakia, followed by those from Poland,

- in the case of Slovaks and Poles, year by year, personal experience has been planning a less important role in trip planning,

- Slovaks, just like the respondents from all the European Union countries in general, assign less and less importance to personal contacts with the employees from traditional travel agencies,

- in the latest of the conducted FL studies from 2016, an in-depth analysis of the Internet sources was carried out, which allowed for identifying the most important ones, both for Poles, Slovaks and, in general, for the EU citizens, such as websites collecting and presenting comments, reviews and ratings from travellers.

Table 9. Source of information for making decisions about travel plans in 2008, 2011 and 2015 (\%)

\begin{tabular}{|c|c|c|c|c|c|c|c|c|c|}
\hline \multirow{3}{*}{ Specification } & \multirow{2}{*}{\multicolumn{3}{|c|}{ Polish }} & \multirow{2}{*}{\multicolumn{3}{|c|}{ Slovaks }} & \multicolumn{3}{|c|}{ EU Citizens } \\
\hline & & & & & & & EU27 & EU27 & EU28 \\
\hline & 2008 & 2011 & 2015 & 2008 & 2011 & 2015 & 2008 & 2011 & 2015 \\
\hline Recommendations of friends, colleagues or relatives & 71 & 62 & 61 & 68 & 55 & 46 & 57 & 52 & 51 \\
\hline Personal experience & 44 & 36 & 30 & 41 & 37 & 30 & 31 & 32 & 33 \\
\hline Internet/total websites & $32 /-$ & $41 /-$ & $-/ 47$ & $25 /-$ & $40 /-$ & $-/ 33$ & $38 /-$ & $40 /-$ & $-/ 44$ \\
\hline $\begin{array}{l}\text { Travel (tourist) agencies (counters of travel agencies } \\
\text { and tourist offices) }\end{array}$ & 10 & 7 & 10 & 20 & 14 & 7 & 22 & 16 & 13 \\
\hline Media (newspaper, radio, TV) & 2 & 7 & 14 & 2 & 2 & 10 & 9 & 7 & 11 \\
\hline Paid for guidebooks and magazines & 5 & 5 & 5 & 2 & 3 & 5 & 12 & 7 & 9 \\
\hline Free catalogues, brochures & 2 & 9 & - & 9 & 11 & - & 14 & 11 & - \\
\hline Websites collecting and presenting comments, reviews & & & & & & & & & \\
\hline and ratings from travelers & - & - & 36 & - & - & 23 & - & - & 34 \\
\hline Websites run by service provider or destination & - & - & 17 & - & - & 17 & - & - & 17 \\
\hline $\begin{array}{l}\text { Social media sites/social media pages (for accommodation, } \\
\text { restaurants, transport companies, etc.) }\end{array}$ & - & 4/- & $-/ 17$ & - & $2 /-$ & $-/ 7$ & - & $5 /-$ & $-/ 12$ \\
\hline
\end{tabular}

Source: authors' compilation based on FL Reports: Survey on the attitudes of Europeans towards tourism, FL258 (2009); Survey on the attitudes of Europeans towards tourism, FL334 (2012); Preferences of Europeans towards tourism, FL432 (2016).

\section{The criteria for assessing the usefulness of secondary sources for analysing tourists' preferences}

The subject literature lists, most frequently, five or $\operatorname{six}^{1}$ factors determining the quality of secondary sources (Daas, Ossen, 2011, pp. 23-836; Kaczmarczyk, 2002, pp. 164-166; Kędzior 2005, pp. 54-59; Mazurek-Łopacińska, 2002, pp. 100-102), although P.W.M. van Nederpelt and P.J.H. Daas (2012, pp. 7-15) list as many as 49 factors that influence the quality of secondary data sources. They determine the usefulness (usability level) of the sources for entrepreneurs, students

${ }^{1}$ The six dimensions by Eurostat are: relevance, accuracy, timeliness and punctuality, accessibility and clarity, comparability, and coherence (Eurostat, 2005). 
or researchers using them. For entrepreneurs, a high level of usefulness of secondary sources means the possibility of making an accurate business decision on their basis, for students - an opportunity to collect reliable knowledge, and for researchers - ability to solve a research problem. Among the existing sources, their users select those that best meet usability criteria. Therefore, prior to a decision-making process or a research problem realization, based on the data from secondary sources, they evaluate them in terms of such characteristics as: accessibility, timeliness, accuracy, relevance (adequacy) and comparability.

The first criterion involves the possibility of reaching and using a specific secondary source. In the era of increasing importance of the Internet in communication, such accessibility is also growing. The institutions which collect data for the purpose of their free of charge or chargeable sharing, generally use the Internet as the distribution channel for the research results or information about the possibilities of their purchase. Financing research from public funds often extends the free access of their results. The wide accessibility of secondary data is also influenced by the fact of recognizing them as a market product, which results in a broad spectrum of research reports on various topics offered by marketing research agencies on the market.

Data timeliness does not only refer to the latest, current phenomena, but also to the adequacy of the period from which the secondary data originate to the information needs of their user. These data, if the need arises, can, and even should, be of retrospective - historical nature, especially when the conducted research covers the phenomena in a dynamic system.

Accuracy stands for the degree of compliance of the secondary measurement results with the actual values of the analysed characteristics. It depends on the professionalism of the entities from which the secondary source originates. Professionalism influences the correctness of the research process and, in particular, the choice of data collection and analysis methods, as well as the selection of the research sample. The accuracy assessment requires learning methodological details of carrying out research and primarily the research methods, size, structure and representativeness of the research sample and the time of conducting research.

Relevance (adequacy) of the secondary sources refers to compliance of the following aspects: subjective, objective, spatial and temporal of the secondary data and the data needed to solve current problem, and a decision maker or a researcher comes across. It is the most difficult and, simultaneously, the most complex determinant of the usefulness of secondary sources for research.

The final characteristic - comparability of the available data is related to the problem of crosssectional (e.g. various market segments), spatial (various territorial units) and/or dynamic (various periods) research. It refers to the accurate measurement (based on the same methods, measurement instruments and other circumstances) of the same characteristics for all cross-sections, spatial units and analysed periods.

The analysis of the abovementioned criteria requires from those using the results of secondary research to answer several important questions, i.e.: (a) what was the purpose of the study; (b) who was responsible for collecting information; (c) what information was actually collected; (d) when was the information collected; (e) how was the information obtained; and (f) how consistent is the 
information obtained from one source with information available from other sources (Johnston, 2014, pp. 619-626).

\section{Conclusions}

The attempt undertaken in the article, i.e. the variability analysis of tourist preferences of Europeans, with particular emphasis on the preferences presented by Poles and Slovaks, based on the data from Flash Eurobarometer, highlighted the imperfection of this source, resulting primarily from the limited comparability of data in a dynamic system. Such assessment is determined by the systematic changes made in the substantive area of the measurement instrument (a questionnaire). They are manifested, among others, by introducing new questions to the questionnaire, changes in the previous ones and also in the response variants. Mentioned changeability significantly reduces the possibility of comparing information in the period under analysis.

Discussed research instrument, developed professionally by the globally operating social and marketing research agency TNS Political \& Social, does provide a lot of information on tourist preferences, however, it is also burdened with certain deficiencies regarding the accuracy and relevance of secondary data. The data collected on the basis of a changeable measurement instrument, in the end, present an insufficiently detailed, inconsistent and fragmentary nature. In consequence, it significantly reduces the usefulness of Flash Eurobarometer as the source of information for e.g. entrepreneurs operating on the tourist market and the representatives of science. By providing knowledge about general behaviour trends of Europeans on the tourism market, they can be used primarily for political purposes (e.g. developing the assumptions of tourism policy on a macro scale), as well as for didactic purposes.

Presented discussion has shown that certain pragmatic conditions occur in which primary data might be substituted by secondary data. It refers to these characteristics which determine the usefulness of secondary sources, such as: accessibility, timeliness, accuracy, relevance (adequacy) and comparability. Simultaneous compliance of each of them is not only difficult but, in most cases, impossible. For this reasons, although the secondary data are probably less expensive, might be less biased and more accessible, these two types of data cannot be referred to as direct substitutes of each other (Cowton, 1998, pp. 423-434). 


\section{Referencencs}

Attitudes of Europeans towards tourism, FL291 (2011). European Commission.

Attitudes of Europeans towards tourism, FL370 (2014). European Commission.

Attitudes of Europeans towards tourism, FL392 (2015). European Commission.

Bazarnik, J., Grabiński, T., Kąciak, E., Mynarski, S., Sagan, A. (1992). Badania marketingowe. Metody i oprogramowane komputerowe. Warszawa-Kraków: Canadian Consortium of Management School - Cracow University of Economics.

Cowton, Ch.J. (1998). The Use of Secondary Data in Business Ethics Research. Journal of Business Ethics, 17, $423-434$.

Daas, P.J.H., Ossen, J.L.S. (2011). Metadata quality evaluation of secondary data sources. International Journal for Quality Research, 2 (5), 23-836.

Entretien avec M.Jacques-René Rabier, fondateur de l'Eurobaromètre Mardi (2003). Retrieved from: http://ec.europa.eu/ commfront office/publicopinion/index.cfm/Archive/index.

Eurobarometer A-Z. List of surveys on 2018-05-28 (2018). Retrieved from: http://ec.europa.eu/commfrontoffice/publicopinion/index.cfm/Archive/index.

Europeans and their Holidays, SP028 (1987). Retrieved from: http:/ec.europa.eu/comm frontoffice/publicopinion/index. cfm/Survey/getSurveyDetail/yearFrom/1986/yearTo/2018/search/HOLIDAY/surveyKy/86, pp. III, 1.

Europeans on holiday, SP117 (1997). Retrieved from: http://ec.europa.eu/comm frontoffice/publicopinion/index.cfm/ Survey/getSurveyDetail/yearFrom/1974/yearTo/1998/search/HOLIDAY/surveyKy/172, pp. III, 15.

Europeans and their views on child sex tourism, SP118 (1998). Retrieved from: http://ec. europa.eu/commfrontoffice/publicopinion/index.cfm/Survey/getSurveyDetail/yearFrom/1974/yearTo/2000/search/sex\%20tourism/surveyKy/173, pp. III, 28.

Eurostat (2005). Standard quality indicators, Quality in statistics. Luxembourg: Eurostat publication.

https://www.gesis.org/eurobarometer-data-service/survey-series/flash-eb/study-overview.

Johnston, M.P. (2014). Secondary Data Analysis: A Method of which the Time Has Come. Qualitative and Quantitative Methods in Libraries, 3, 619-626.

Kowalik. S. (1994). Zachowania konsumenckie - Teoria preferencji-Reklama. Journal of Law, Economics and Sociology, 2 (LVI), 97-111.

van Nederpelt, P.W.M., Daas, P.J.H. (2012). 49 factors that influence the quality of secondary data sources. Hague: Statistics Netherlands.

Pełka, M., Rybicka, A. (2012). Pomiar i analiza preferencji wyrażonych z wykorzystaniem pakietu conjoint programu R. Statistical Review, 3 (LIX), 302-315.

Preferences of Europeans towards tourism, FL414 (2015). European Commission.

Preferences of Europeans towards tourism, FL432 (2016). European Commission.

Spotlight on European public opinion in 2013. A Eurobarometer Almanac (2014). European Commission, Publishing Office. Retrieved from: http://ec.europa.eu/commfrontoffice/publicopinion/index.cfm/Archive/index.

Survey on the attitudes of Europeans towards tourism, FL258 (2010). European Commission.

Survey on the attitudes of Europeans towards tourism, FL328 (2012). European Commission.

Survey on the attitudes of Europeans towards tourism, FL334 (2013). European Commission.

Szymańska, A.I. (2012). Preferencje konsumeckie i ich determinanty. Zeszyty Naukowe Wyższej Szkoty Ekonomii i Informatyki w Krakowie, 8, 67-86. 


\section{PRZYDATNOŚĆ FLASH EUROBAROMETRU DO BADANIA ZMIAN PREFERENCJI TURYSTÓW}

SŁOWA KLUCZOWE

STRESZCZENIE
Flash Eurobarometr, preferencje turystów, źródło informacji

Skuteczne działania przedsiębiorstw turystycznych wymaga m.in. dobrej znajomości preferencji nabywczych klientów. Pomocne w tym zakresie mogą być źródła wtórne np. dostępne raporty badawcze. Celem artykułu jest ocena przydatności wyników badań Flash Eurobarometr do analizy zmian w preferencjach turystycznych Europejczyków, ze szczególnym uwzględnieniem Polaków i Słowaków. Okazuje się, że wspomniane źródło informacji nie jest pozbawione mankamentów. Chodzi przede wszystkim o systematyczne zmiany dokonywane w zakresie przedmiotowym instrumentu pomiarowego, tj. ankiety. Polegają one na wprowadzaniu do ankiety nowych pytań, zmian w pytaniach dotychczasowych oraz wariantach odpowiedzi na pytania. Zmienność ta obniża w sposób istotny możliwość porównania informacji w badanym okresie i ich użyteczność dla przedsiębiorców i przedstawicieli świata nauki. 